\title{
Nem invazív lélegeztetés alkalmazása kritikus állapotú betegekben
}

\author{
Valkó Luca dr. - Baglyas Szabolcs dr. - Tamáska Eszter dr. \\ Lorx András dr. - Gál János dr.
}

Semmelweis Egyetem, Általános Orvostudományi Kar, Aneszteziológiai és Intenzív Terápiás Klinika, Budapest

Bevezetés: A nem invazív lélegeztetés alkalmazása világszerte terjed. Számos kórkép esetén bizonyították mortalitásbeli előnyét az invazív lélegeztetéssel szemben. A technika leggyakoribb ellenérvei a nagy eszköz- és ellátó személyzeti igény, valamint a sikertelen kezeléssel járó fokozott mortalitás.

Célkitưzés: Jelen munkánk célja az volt, hogy bemutassuk az intenzív osztályon alkalmazott nem invazív lélegeztetéssel nyert tapasztalatainkat.

Módszer: A Semmelweis Egyetemen 2014 és 2016 között múködő Légzési Intenzív Osztály nem invazív lélegeztetéssel kezelt betegeinek adatait dolgoztuk fel retrospektív módon. A statisztikai elemzést Mann-Whitney-féle Uteszttel, illetve Z-teszttel, a rizikóarány-számítást $\chi$-négyzet-próbával végeztük.

Eredmények: A vizsgált 301 beteg közül 147 részesült iniciális nem invazív lélegeztetésben. A konverziós arány 24,5\% volt. A legnagyobb sikertelenségi arány az immundeficientiához kapcsolt tüdőgyulladás, az interszticiális tüdőbetegség és a tüdőgyulladásos kórképekhez volt köthető $(71,4 \%, 33,3 \%$, illetve 31,6\%), míg a nem invazív lélegeztetés cardialis tüdőödémában és hypercapniás légzési elégtelenségben volt a legsikeresebb (0\%-os, illetve 16,7\%-os konverziós igény). A konverzióra szoruló betegcsoport mortalitása (33,3\%) szignifikánsan magasabb volt mind az iniciálisan invazívan lélegeztetett $(24,5 \%)$, mind a sikeresen nem invazívan lélegeztetett betegcsoporténál (3,6\%); az iniciális invazív lélegeztetési igény 2,65-szörös mortalitásemelkedést $(\mathrm{OR}=2,65,95 \% \mathrm{CI}=1,305-5,374, \mathrm{p}=0,009)$, a lélegeztetés konverziójának szükségessége 13,33-szoros mortalitásemelkedést $(\mathrm{OR}=13,33$; 95\% CI 3,278-54,238; $\mathrm{p}<0,001)$ jelentett. Az intenzíves mortalitást számoló pontrendszerek nem jelezték előre a sikertelen nem invazív lélegeztetést.

Következtetés: A nem invazív lélegeztetés magyar viszonylatban is széles körű indikációval, sikeresen alkalmazható kezelési mód, mely bizonyos kórképekben javítja a túlélést az invazív lélegeztetéssel szemben. A nem megfelelő indikációval végzett nem invazív lélegeztetés sikertelensége és várható mortalitása fokozott lehet.

Orv Hetil. 2018; 159(45): 1831-1837.

Kulcsszavak: nem invazív/noninvazív lélegeztetés, légzési elégtelenség, sikertelen terápia

\section{Use of noninvasive ventilation in critically ill patients}

Introduction: The use of noninvasive ventilation has increased worldwide. Its mortality reducing benefit has been shown in several different conditions compared to invasive ventilation. Common counterarguments against the technique are its increased technical and caregiver requirements and increased mortality associated with treatment failure. Aim: The aim of our work was to describe our experiences with noninvasive ventilation in the intensive care unit. Method: We reviewed patient data from the Respiratory Intensive Care unit of Semmelweis University operated from 2014 to 2016. Statistical analysis was performed by Mann-Whitney U test and Z-test; odds ratio was calculated with $\chi$-square test.

Results: Out of the 301 patients analyzed, 147 received noninvasive ventilation. Noninvasive failure rate was $24.5 \%$. The highest failure rate was associated with immunodeficiency associated pneumonia, interstitial lung disease and pneumonia $(71.4 \%, 33.3 \%$ and $31.6 \%)$, while noninvasive ventilation was the most successful in cardiogenic pulmonary edema and hypercapnic respiratory failure $(0$ and $16.7 \%$ failure rate). Treatment failure was associated with significantly higher mortality (33.3\%) compared to patients initially ventilated invasively $(24.5 \%)$ and patients successfully treated with noninvasive ventilation $(3.6 \%)$, resulting in a 2.65 -fold mortality increase in invasively ventilated patients $(\mathrm{OR}=2.65,95 \% \mathrm{CI}=1.305-5.374, \mathrm{p}=0.009)$, and a 13.33 -fold mortality increase in noninvasive failure patients $(\mathrm{OR}=13.33 ; 95 \% \mathrm{CI} 3.278-54.238 ; \mathrm{p}<0.001)$. Outcome scores did not predict noninvasive failure. 
Conclusion: Noninvasive ventilation is a widely used, effective treatment mode which can improve the outcome in certain diseases compared to invasive ventilation. Noninvasive ventilation in incorrect indications could, however, lead to increased failure rates and mortality.

Keywords: noninvasive ventilation, respiratory insufficiency, treatment failure

Valkó L, Baglyas Sz, Tamáska E, Lorx A, Gál J. [Use of noninvasive ventilation in critically ill patients]. Orv Hetil. 2018; 159(45): 1831-1837.

(Beérkezett: 2018. április 10.; elfogadva: 2018. június 11.)

\begin{abstract}
Rövidítések
APACHE II = (Acute Physiology And Chronic Health Evaluation II); ARDS = (adult respiratory distress syndrome) akut légzési distressz szindróma; $\mathrm{CI}=$ (confidence interval) konfidenciaintervallum; COPD $=($ chronic obstructive pulmonary disease) krónikus obstruktív tüdőbetegség; IV = (invasive ventilation) invazív lélegeztetés; NIV = (noninvasive ventilation) nem invazív lélegeztetés; $\mathrm{OR}=$ (odds ratio) esélyhányados; PEEP $=($ positive end expiration pressure $)$ pozitív végkilégzési nyomás; SAPS II = Simplified Acute Physiology Score II; SE = Semmelweis Egyetem; SE AITK LIO = Semmelweis Egyetem, Aneszteziológiai és Intenzív Terápiás Klinika, Légzési Intenzív Osztály
\end{abstract}

A nem invazív lélegeztetés olyan pozitív nyomású lélegeztetési mód, mely a lélegeztetőgép és a beteg légzőrendszere közti folytonosságot jól illeszkedő maszkot tartalmazó légzőkör segítségével teremti meg. A technikai fejlődés következtében a mai nem invazív lélegeztető rendszerek igen jó illeszkedést, kifinomult szabályozást és széles terápiás lehetőségeket tesznek lehetővé. A nem invazív technikával csökkenthetők az invazív lélegeztetéshez asszociált, a kimenetelt negatívan befolyásoló szövődmények, mint a nosocomialis fertőzések, a jelentős szedációs igény és az izmok dekondicionálása. Mindezek következtében a nem invazív gépi lélegeztetés felhasználása az elmúlt évtizedekben világszerte nőtt [1], mára pedig a módszernek számos jól definiált kórképben sikerült igazolni előnyét az invazív lélegeztetési móddal szemben [2]. E kórképekben (például cardialis tüdőödéma, hypercapniás légzési elégtelenség, immunkompromittáltak tüdőgyulladásához kapcsolt légzési elégtelenség) a nem invazív lélegeztetés egyértelmú, akár négyszeres mortalitáscsökkenést eredményez az invazív lélegeztetési módhoz képest, de jól megválasztott esetekben egyéb kórképekben (például tüdőgyulladáshoz kapcsolt légzési elégtelenség, posztoperatív légzési elégtelenség, akut hypoxiás légzési elégtelenség) is lehet klinikai előnye [3-7]. Ugyanakkor a nem invazív lélegeztetés sikertelensége, mely az esetek 5-60\%-ában fordul elő, ismerten mortalitásfokozó hatású [8], így a megfelelő betegek kiválasztása, az egyénre szabott optimalizált terápia és az adekvát nem invazív lélegeztetés biztosítása kulcsfontosságú a kimenetel szempontjából. A nem invazív lélegeztetés széles körű felhasználását limitálhatja a sikertelenségtől való félelem, továbbá nagy eszköz-, illetve szakképzett személyzeti igénye [9], ugyanakkor egyes tanulmányok szerint a nem invazív lélegeztetésben tapasztalatot szerző és a technikát rendszeresen alkalmazó osztályok a tapasztalatuk növekedésével egyre súlyosabb betegeket képesek biztonsággal és sikeresen kezelni [10].

A nem invazív lélegeztetés alkalmazásáról világszerte több adatunk van, azonban a noninvazív lélegeztetés közép- és kelet-európai felhasználásáról limitáltak az információink [11]. Egy 2011-es lengyel tanulmány alacsonynak találta a nem invazív lélegeztetés technikájának alkalmazását [12], a közlések hiánya pedig valószínúleg a technika európai alkalmazásának nem homogén megoszlását tükrözi [13].

Magyarországon a nem invazív lélegeztetés intenzív osztályokon az 1990-es években a korszerű eszközöknek köszönhetően új lendületet kapott [14], 2011 óta a technikát dedikált nem invazív lélegeztetési osztályon is alkalmazzák [15]; a technika oktatása évek óta az intenzív terápiás és a tüdőgyógyászati szakképzés része, az országos mentőszolgálat pedig eljárási rendje alapján a prehospitális ellátásban is alkalmazza. Az egyértelmű klinikai előnyök ellenére a magyarországi intenzív osztályokon a nem invazív lélegeztetés - jelentős eszközigénye, a tapasztalt szakemberek és a rendszeres képzés hiánya miatt - továbbra is alulreprezentált.

\section{Módszer}

Jelen tanulmányunkban a Semmelweis Egyetem Aneszteziológiai és Intenzív Terápiás Klinikájának 6 ágyas Légzési Intenzív Osztályán (SE AITK LIO) 2014. január és 2016. március között kezelt betegek adatait retrospektíven dolgoztuk fel. Célkitüzésünk az volt, hogy Magyarországon először felmérjük, hogy a nemzetközi gyakorlathoz képest a nem invazív technika alkalmazása, egy ezen technikában jártas osztályon, milyen gyakoriságú és sikerességü, valamint milyen a technika alkalmazása kapcsán észlelt várható és tényleges kimenetel aránya.

Az SE AITK LIO beteganyaga primeren légzési elégtelenségben szenvedő, de intenzív terápiás ellátást igénylő (tehát nem izolált szervi elégtelenségben szenvedő) felnőtt betegekből állt; a betegek többsége az SE Pulmonológiai Klinikájáról került felvételre progresszív beteg- 
ellátás keretében. Az osztályon magas arányban alkalmaztunk nem invazív lélegeztetést, melyet egyszáras, réslevegős rendszerrel múködő dedikált nem invazív lélegeztetőgépekkel (Synchrony, A30, A40, Trilogy, Philips Respironics, illetve VPAP, Resmed Ltd., Blacktown, Ausztrália) végeztünk. A terápiát helyi gyakorlat szerint alkalmazott indikációkban, iniciálisan arcmaszkon keresztül nyomáskontrollált módban, 12-35 vízcm-es csúcsnyomással, 4-10 vízcm-es kilégzési nyomással, 6-8 $\mathrm{ml} / \mathrm{ttkg}$-os célvolumennel, iniciálisan minimum 20-24 óra/nap időtartamban végeztük szükség esetén dexmedetomidinszedációban. A nem invazív lélegeztetés mint kezelési mód elsősorban olyan, igazolt indikációs körökben jött szóba, ahol nem fokális intrapulmonalis eltérés (például kiterjedt pneumonia) volt a kórok, a légzési munka csökkentése és az adekvát pihenés kifejezett cél volt, illetve a váladékretenció veszélye nem állt fenn. A nem invazív lélegeztetést ellenjavalltnak tartottuk tudatzavar, a kooperáció hiánya, jelentős keringési instabilitás és váladékretenció esetén. A NIV-kezelést nem kezdtük el, ha az alapbetegség miatt a NIV nem javasolt (több lebenyt érintő tüdőgyulladás, ARDS). Azok a betegek, akiknek állapotromlása a primeren megkezdett nem invazív lélegeztetés folytatását nem tette lehetővé (adekvát nem invazív lélegeztetés ellenére perzisztáló hypoxia, hypercapnia; új keletű keringési instabilitás vagy tudatzavar, illetve akut sebészi vagy intervenciós beavatkozást igénylő kórkép kifejlődése), konverzióra kerültek, és lélegeztetésüket invazív módon folytattuk. Az interszticiális tüdőbetegségben szenvedőknél az iniciális nem invazív lélegeztetés a kórkép progresszív volta miatt jellemzően palliatív jellegü volt. Az SE AITK LIO nem rendelkezett házon belüli sebészi és cardialis intervenciós háttérrel, így a sebészeti vagy intervenciós okból áthelyezett betegek kiestek az utánkövetésből, ami rejtett mortalitáshoz járulhatott hozzá. Ugyanakkor ezek a betegek nem igazi nem invazív lélegeztetési sikertelenséget jelentenek, hiszen az intubáció sok esetben a szállítás során nem biztosítható nem invazív lélegeztetés miatt volt szükséges.

Az invazív lélegeztetést kétszáras, aktív párásítást tartalmazó lélegeztetőgépekkel (Evita XL Dräger, Lübeck, Németország; Servo-i Maquet, Solna, Svédország; Raphael Hamilton, Rhäzuns, Svájc), iniciálisan nyomásvagy volumenkontrollált módban, $6-8 \mathrm{ml} / \mathrm{ttkg}$ célvolumennel, betegség és oxigenizáció alapján titrált PEEP és percventiláció mellett végeztük. Az osztály helyi gyakorlata alapján a primer légzéstámogatás fajtájának megválasztása, illetve a konverzió szükségességének meghatározása az osztályos, illetve ügyeletes orvos kompetenciája volt.

A betegek kórlapjaiból nyert adatokat retrospektíven feldolgozva vizsgáltuk a nem invazív technika alkalmazásának gyakoriságát, a nem invazív technika sikerességét befolyásoló tényezőket és a nem invazív technika sikerességének és sikertelenségének hatását a mortalitásra. A várható mortalitást az APACHE II (Acute Physiology And Chronic Health Evaluation II), illetve a SAPS II
(Simplified Acute Physiology Score II) pontrendszerek alapján mértük fel, melyek a felvételt követő 24 órában észlelt szervi funkciós paramétereken alapuló intenzíves mortalitásprediktáló számlálók, így jól tükrözik a kritikus állapotú betegek felvételi kórállapotának súlyosságát.

A folytonos változó adatokat medián (interkvartilis tartomány) formában, a kategorikus változókat abszolút értékben tüntettük fel. A normalitás ellenőrzésére Shapiro-Wilk-tesztet alkalmaztunk. Mivel adataink nem normáleloszlást követtek, az összehasonlító elemzést az egyes csoportok között Mann-Whitney-féle U-teszttel végeztük. A rizikóarány-számítást $\chi$-négyzet-próbával végeztük. A várható és a tényleges mortalitások közötti összehasonlítást Z-teszttel végeztük. Egy csoport várt mortalitását a csoportban szereplő betegek egyedenként számolt pontszámaiból származtatott várt mortalitások átlagából nyertük. Minden statisztikai tesztnél 95\%-os konfidenciaintervallumot vettünk figyelembe, a használt szignifikanciahatár $\mathrm{p}<0,05$ volt. A statisztikai számításokat SigmaPlot 12 (Systat Software, San Jose, Kalifornia, Amerikai Egyesült Államok) programmal végeztük.

\section{Eredmények}

A vizsgált időszakban összesen 301 beteg került felvételre. A 301 betegnél a férfi : nő arány 48,8 : 51,2\%, a kor $64(53 ; 72)$ év, a felvételi APACHE II 20 (16; 25) pont (várt mortalitás: 37,5\%), a felvételi SAPS II $37(29 ; 48)$ pont (várt mortalitás: $38,5 \%$ ) volt. A tényleges mortalitás (16,9\%) a várt mortalitásokhoz képest szignifikánsan kisebb volt $(\mathrm{p}<0,001$, illetve $\mathrm{p}<0,001)$. A betegek $2,7 \%$-a ( 8 beteg) otthoni lélegeztetési program keretében tartós légzéstámogatáson maradt.

A 301 betegből 147 beteg $(48,8 \%)$ részesült iniciális invazív légzéstámogatásban, míg 110 betegnél (36,5\%) a kezdeti légzéstámogatás nem invazív lélegeztetés volt, továbbá 44 beteg $(14,6 \%)$ nem részesült légzéstámogatásban, csak oxigénterápiában és légzési fizioterápiában (1. ábra). A leggyakoribb lélegeztetés indikációját képező felvételi diagnózisok a pneumonia, a COPD akut exacerbatiója, a cardiogen eredetû tüdőödéma, az interszticiális tüdőbetegség, az immunkompromittáltak pneumoniája voltak. Kis esetszámban egyéb diagnózisok is előfordultak, mint például pulmonalis hypertonia (9), pulmonalis embolia (5), asztma (2).

Az iniciálisan invazívan és iniciálisan nem invazívan lélegeztetett betegek adatainak és jellemzőinek összehasonlítását az 1. táblázat tartalmazza.

Az iniciálisan invazívan és nem invazívan lélegeztetett betegek életkora és neme nem különbözött egymástól. A kétféleképpen kezelt betegek csoportja a felvételi diagnózis szempontjából eltérő volt. Az iniciálisan invazívan lélegeztetett betegeknél gyakoribb volt a tüdőgyulladás ( 49 vs. $34,5 \%, p=0,011$ ), mint a nem invazívan lélegeztetett betegeknél. Az iniciálisan nem invazívan lélegeztetett betegeknél nem volt különbség a COPD (krónikus obstruktív tüdőbetegség) akut exacerbatiója (hypercap- 


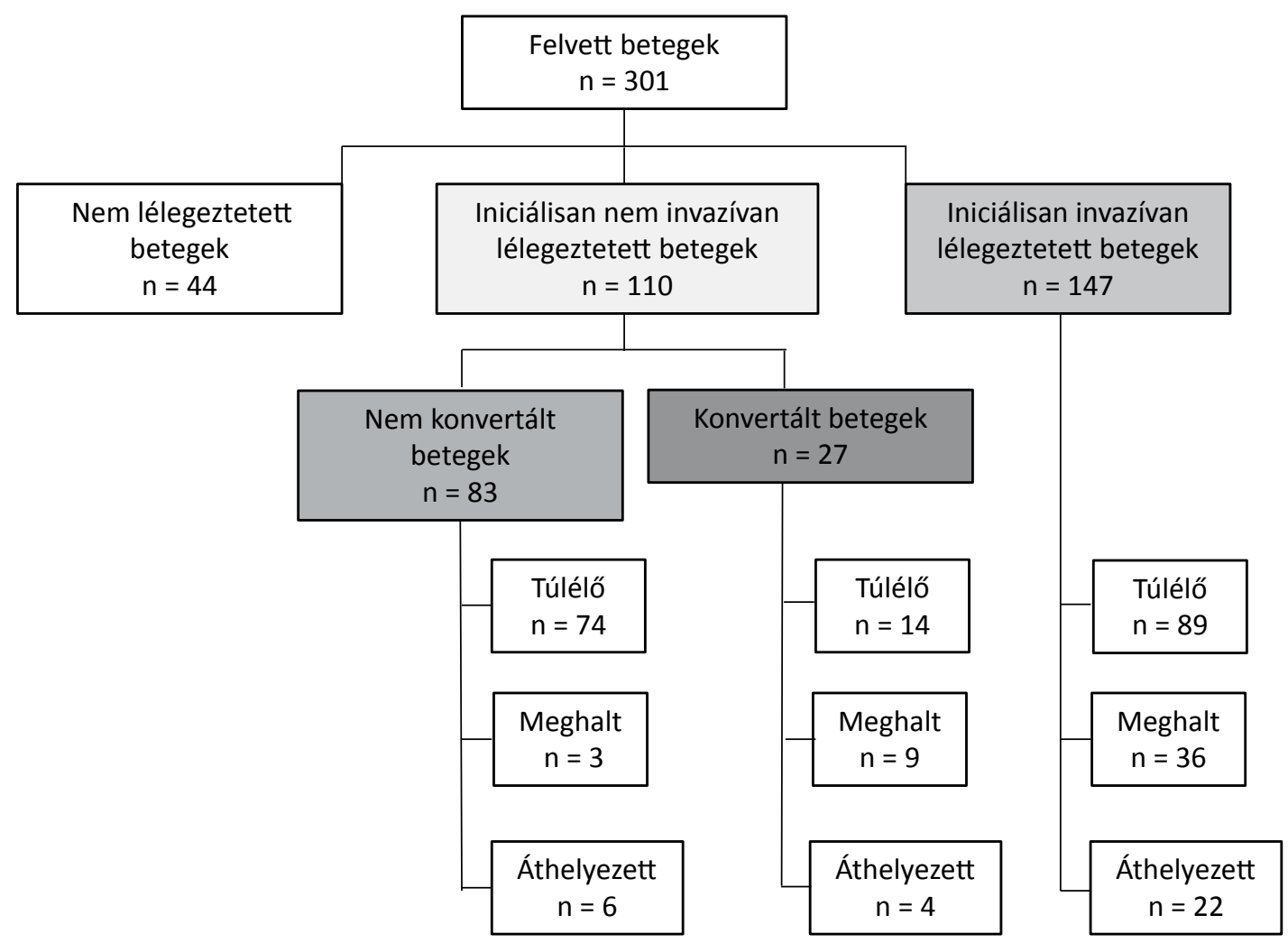

1. ábra

niás légzési elégtelenség), a cardialis dekompenzáció, az interszticiális tüdőbetegség és az immundeficientiához társult tüdőgyulladás előfordulásában (1. táblázat).

Az iniciálisan invazívan lélegeztetett betegek APACHE II- és SAPS II-pontszáma magasabb volt az iniciálisan nem invazívan lélegeztetett betegekénél (21 vs. 19; p = $0,002$, illetve 43 vs. $33 ; \mathrm{p}<0,001)$.

$\mathrm{Az}$ iniciálisan nem invazívan lélegeztetett 110 betegből a nem invazív lélegeztetés 27 esetben (24,5\%) volt sikertelen, és konverzióra, invazív lélegeztetésre volt szükség. A nem konvertált (végig nem invazív lélegeztetés) és a konvertált csoport betegeinek adatait és jellemzóit a 2. táblázat tartalmazza.

A konvertált betegcsoport a demográfiai adatok alapján nem különbözött a végig nem invazív lélegeztetéssel kezelhető csoporttól. Az egyes betegcsoportokat vizsgálva a legmagasabb konverziós rátát az immundeficientiához kötött tüdőgyulladás (71,4\%; 7-ból 5 beteg), az interszticiális tüdőbetegségek $(33,3 \%$; 9-ből 3 beteg) és a tüdőgyulladás kapcsán észleltük $(31,6 \%$; 36-ból 12 beteg), míg a kezelés a cardiogen eredetű tüdőödéma $(0 \%$; 11-ből 0 beteg) és a COPD akut exacerbatiója esetén (16,7\%; 30-ból 5 beteg) volt a legsikeresebb.

A két pontrendszer (APACHE II, SAPS II) által számolt várható mortalitásban nem volt különbség sem az iniciálisan invazívan, sem a végig nem invazívan lélegeztetett betegek esetén $(43,7 \%$, illetve $48,9 \%, p=0,349$; valamint $33,7 \%$, illetve $29,3 \%, p=0,503)$, de mindkét pontrendszer szignifikánsan felülbecsülte a tényleges mortalitást ezekben a betegcsoportokban (2. ábra). A pontrendszerek csak a konvertált, nem invazívan lélegeztetett csoportban prediktálták pontosan a mortalitást.

A konverzióra szoruló betegcsoport mortalitása (33,3\%) magasabb volt mind az iniciálisan invazívan lélegeztetett $(24,5 \%)$, mind a sikeresen nem invazívan lélegeztetett betegcsoporténál $(3,6 \%)$; az iniciális invazív lélegeztetési igény 2,65-szörös mortalitásemelkedést $(\mathrm{OR}=2,65,95 \% \mathrm{CI}=1,305-5,374, \mathrm{p}=0,009)$, a lélegeztetés konverziójának szükségessége 13,33-szoros mortalitásemelkedést $(\mathrm{OR}=13,33 ; 95 \%$ CI 3,27854,238; $\mathrm{p}<0,001)$ jelentett.

A felvételi diagnózisok kimenetelt befolyásoló hatását a 3. táblázatban összesítettük.

A leggyakoribb felvételi diagnózis a tüdőgyulladás volt (40,2\%), mely az esetek 61,9\%-ában invazív lélegeztetést igényelt. Az iniciálisan nem invazívan lélegeztetett pneumoniás betegek 31,6\%-ban konverziót igényeltek, ebben a csoportban azonban a mortalitás nem volt emelkedett az iniciálisan invazívan lélegeztetett csoporthoz képest. A konverzió nem járt statisztikailag igazolható mortalitásemelkedéssel.

\section{Megbeszélés}

Az intenzív osztályokon kezelt betegek nagy száma igényel légzéstámogatást [16]. Jelen vizsgálatunk az első olyan magyarországi munka, mely intenzív osztályos beteganyagon a nem invazív lélegeztetés igen magas fel- 
Az iniciálisan invazívan és nem invazívan lélegeztetett betegek összehasonlítása

\begin{tabular}{|c|c|c|c|}
\hline & $\begin{array}{l}\text { Iniciális invazív } \\
\text { lélegeztetés }\end{array}$ & $\begin{array}{l}\text { Iniciális nem } \\
\text { invazív } \\
\text { lélegeztetés }\end{array}$ & \\
\hline Betegszám & 147 & 110 & \\
\hline Férfi : nó arány $(\mathrm{n})$ & $\begin{array}{l}50,3 \%: 49,7 \% \\
(74: 73)\end{array}$ & $\begin{array}{l}46,4 \%: 53,6 \% \\
(51: 59)\end{array}$ & $\mathrm{p}=0,529$ \\
\hline Kor (év) & $66(56 ; 73)$ & $63,5(54 ; 71)$ & $\mathrm{p}=0,310$ \\
\hline \multicolumn{4}{|l|}{ Etiológiai arány (n) } \\
\hline Pneumonia & $51,0 \%(75)$ & $34,5 \%(38)$ & $\mathrm{p}=0,011$ * \\
\hline $\begin{array}{l}\text { COPD akut } \\
\text { exacerbatio }\end{array}$ & $17,7 \%(26)$ & $27,3 \%(30)$ & $\mathrm{p}=0,069$ \\
\hline $\begin{array}{l}\text { Cardiogen eredetű } \\
\text { tüdőödéma }\end{array}$ & $8,2 \%(12)$ & $10,0 \%(11)$ & $\mathrm{p}=0,662$ \\
\hline $\begin{array}{l}\text { Interszticiális } \\
\text { tüdőbetegség }\end{array}$ & $3,4 \%(5)$ & $8,2 \%(9)$ & $\mathrm{p}=0,105$ \\
\hline $\begin{array}{l}\text { Immundeficientiá- } \\
\text { hoz kötött } \\
\text { pneumonia }\end{array}$ & $5,4 \%(8)$ & $6,4 \%(7)$ & $\mathrm{p}=0,793$ \\
\hline Egyéb indikáció & $14,9 \%(21)$ & $13,6 \%(15)$ & $\mathrm{p}=1$ \\
\hline APACHE II & $21(17 ; 29)$ & $19(16 ; 23)$ & $\mathrm{p}=0,002^{*}$ \\
\hline $\begin{array}{l}\text { Várt mortalitás az } \\
\text { APACHE II alapján }\end{array}$ & $43,7 \%$ & $33,8 \%$ & $\mathrm{p}<0,001^{* *}$ \\
\hline SAPS II & $43(34 ; 56)$ & $33(27 ; 41)$ & $\mathrm{p}<0,001^{* *}$ \\
\hline $\begin{array}{l}\text { Várt mortalitás a SAPS } \\
\text { II alapján }\end{array}$ & $48,9 \%$ & $29,7 \%$ & $\mathrm{p}<0,001^{* *}$ \\
\hline $\begin{array}{l}\text { A tényleges mortalitás } \\
\text { aránya }(\mathrm{n})\end{array}$ & $24,5 \%(36)$ & $10,9 \%(12)$ & $\mathrm{p}=0,006^{*}$ \\
\hline Kezelési napok & $11(5 ; 16)$ & $4(3 ; 10)$ & $\mathrm{p}<0,001^{* *}$ \\
\hline
\end{tabular}

Magyarázat: A folytonos változó adatokat medián (interkvartilis tartomány) formában, a kategorikus változókat abszolút értékben tüntettük fel százalékos (elemszám-) formátumban. ${ }^{*} \mathrm{p}<0,05,{ }^{*}{ }^{*}<\mathrm{p}<0,001$

APACHE II = akut fiziológiai és krónikus egészségfelmérés II; COPD = krónikus obstruktív tüdőbetegség; SAPS II = egyszerűsített akut fiziológiai pontrendszer II
2. táblázat A végig nem invazívan kezelt, illetve nem invazívról invazív lélegeztetésre konvertált betegcsoport adatai és jellemzői

\begin{tabular}{|c|c|c|c|}
\hline & $\begin{array}{l}\text { Nem } \\
\text { konvertált } \\
\text { betegek }\end{array}$ & $\begin{array}{l}\text { Konvertált } \\
\text { betegek }\end{array}$ & \\
\hline Betegszám & 83 & 27 & \\
\hline Férfi : nő arány (n) & $\begin{array}{l}47 \%: 53 \% \\
(39: 44)\end{array}$ & $\begin{array}{l}40,7 \%: 59,3 \% \\
(12: 15)\end{array}$ & $\mathrm{p}=0,505$ \\
\hline Kor (év) & $63(53,5 ; 71)$ & $64(54 ; 72)$ & $\mathrm{p}=0,784$ \\
\hline \multicolumn{4}{|l|}{ Etiológiai arány (n) } \\
\hline Pneumonia & $31,3 \%(26)$ & $44,4 \%(12)$ & $\mathrm{p}=0,248$ \\
\hline $\begin{array}{l}\text { COPD akut } \\
\text { exacerbatio }\end{array}$ & $30,1 \%(25)$ & $18,5 \%(5)$ & $\mathrm{p}=0,322$ \\
\hline $\begin{array}{l}\text { Cardiogen eredetü } \\
\text { tüdőödéma }\end{array}$ & $13,3 \%(11)$ & $0 \%(0)$ & $\mathrm{p}=0,062$ \\
\hline $\begin{array}{l}\text { Interszticiális } \\
\text { tüdőbetegség }\end{array}$ & $7,2 \%(6)$ & $11 \%(3)$ & $\mathrm{p}=0,686$ \\
\hline $\begin{array}{l}\text { Immundeficientiá- } \\
\text { hoz kötött } \\
\text { pneumonia }\end{array}$ & $2,4 \%(2)$ & $18,5 \%(5)$ & $\mathrm{p}=0,009^{*}$ \\
\hline Egyéb indikáció & $15,7 \%(13)$ & $7,4 \%(2)$ & $\mathrm{p}=0,351$ \\
\hline APACHE II & $19(16 ; 23)$ & $20(16 ; 22)$ & $\mathrm{p}=0,917$ \\
\hline $\begin{array}{l}\text { Várt mortalitás az } \\
\text { APACHE II alapján }\end{array}$ & $33,7 \%$ & $34,8 \%$ & $\mathrm{p}=0,641$ \\
\hline SAPS II & $33(27 ; 41)$ & $35(28 ; 41)$ & $\mathrm{p}=0,410$ \\
\hline $\begin{array}{l}\text { Várt mortalitás a SAPS } \\
\text { II alapján }\end{array}$ & $29,3 \%$ & $30,9 \%$ & $\mathrm{p}=0,638$ \\
\hline $\begin{array}{l}\text { A tényleges mortalitás } \\
\text { aránya }(\mathrm{n})\end{array}$ & $3,6 \%(3)$ & $33,3 \%(9)$ & $\mathrm{p}<0,001$ * * \\
\hline Kezelési napok & $4(2 ; 7)$ & $11(5,5 ; 19,5)$ & $\mathrm{p}<0,001$ * * \\
\hline
\end{tabular}

Magyarázat: A folytonos változó adatokat medián (interkvartilis tartomány) formában, a kategorikus változókat abszolút értékben tüntettük fel százalékos (elemszám-) formátumban. ${ }^{*} \mathrm{p}<0,05,{ }^{*} \mathrm{p}<0,001$

APACHE II = akut fiziológiai és krónikus egészségfelmérés II; COPD = krónikus obstruktív tüdőbetegség; SAPS II = egyszerúsített akut fiziológiai pontrendszer II

3. táblázat |Az egyes kórképek mortalitása a különböző betegcsoportokon belül

\begin{tabular}{|c|c|c|c|c|}
\hline & $\begin{array}{c}\text { IV lélegeztetett } \\
\text { betegek }\end{array}$ & $\begin{array}{l}\text { NIV lélegeztetett } \\
\text { betegek }\end{array}$ & $\begin{array}{c}\text { Nem konvertált } \\
\text { betegek }\end{array}$ & $\begin{array}{l}\text { Konvertált } \\
\text { betegek }\end{array}$ \\
\hline A pneumonia mortalitása & $22,7 \%(17 / 75)$ & $7,9 \%(3 / 38)$ & $3,8 \%(1 / 26)$ & $16,7 \%(2 / 12)$ \\
\hline A COPD akut exacerbatio mortalitása & $30,7 \%(8 / 26)$ & $3,3 \%(1 / 30)$ & $0 \%(0 / 25)$ & $20 \%(1 / 5)$ \\
\hline A cardiogen eredetű tüdőödéma mortalitása & $66,7 \%(8 / 12)$ & $0 \%(0 / 11)$ & $0 \%(0 / 11)$ & $0 \%(0 / 0)$ \\
\hline Az interszticiális tüdőbetegség mortalitása & $60 \%(2 / 5)$ & $22,2 \%(2 / 9)$ & $0 \%(0 / 6)$ & $66,7 \%(2 / 3)$ \\
\hline Az immundeficientiához kötött pneumonia mortalitása & $12,5 \%(1 / 8)$ & $28,6 \%(2 / 7)$ & $0 \%(0 / 2)$ & $40 \%(2 / 5)$ \\
\hline Az egyéb indikáció mortalitása & $14,3 \%(3 / 21)$ & $26,7 \%(4 / 15)$ & $15,4 \%(2 / 13)$ & $100 \%(2 / 2)$ \\
\hline
\end{tabular}

Magyarázat: A mortalitást abszolút értékben tüntettük fel százalékos (elhunyt beteg/érintett betegszám) formátumban

COPD = krónikus obstruktív tüdőbetegség; IV = invazív; NIV = nem invazív lélegeztetés 

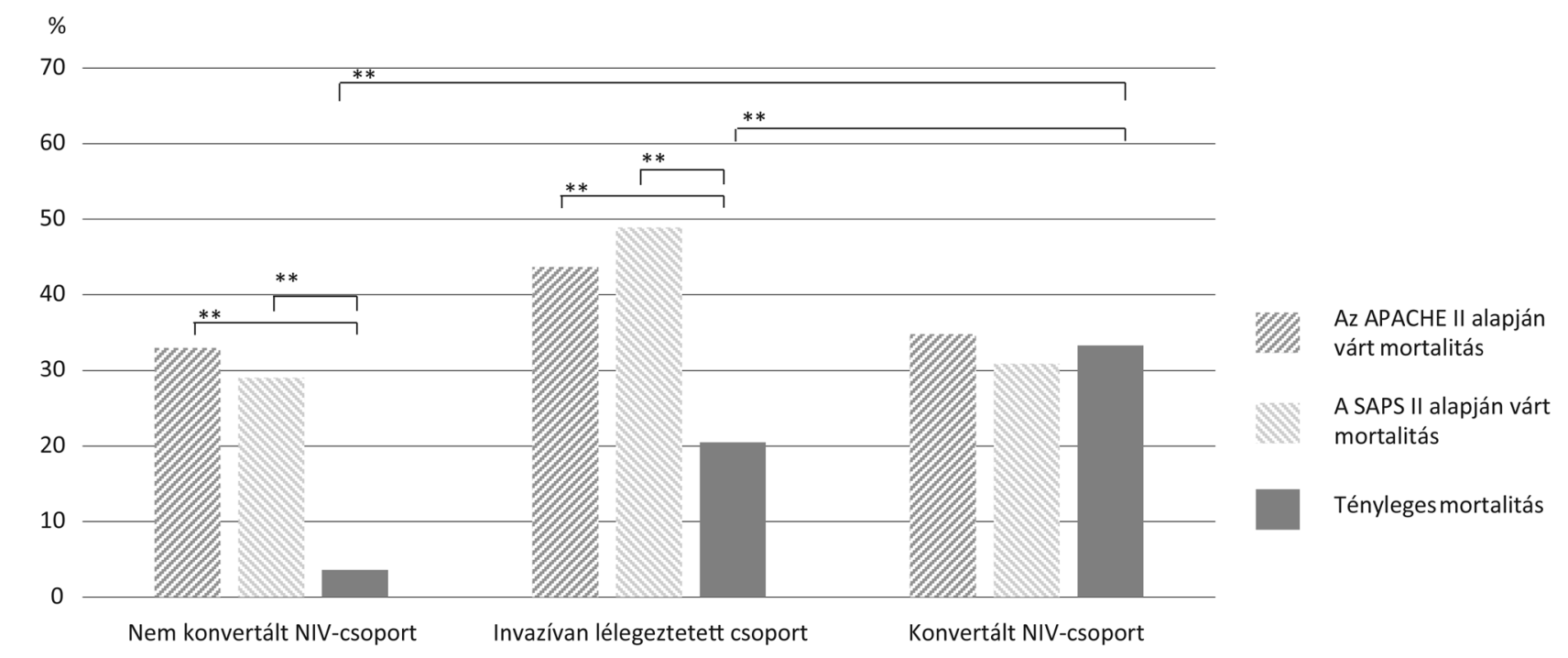

2. ábra $\quad$ A várt és a tényleges mortalitások (százalékban kifejezve) az egyes betegcsoportokban

$$
\begin{aligned}
& \text { Magyarázat: }{ }^{*}{ }^{*}<\mathrm{p}<0,001 \\
& \text { APACHE II. = ; SAPS }=
\end{aligned}
$$

használhatóságát és hatékonyságát igazolja. Adatainkat erősíti az a tény, hogy a Semmelweis Egyetem Aneszteziológiai és Intenzív Terápiás Klinikájának Légzési Intenzív Osztálya mellett egy, a Pulmonológiai Klinika által múködtetett 6 ágyas Neminvazív Lélegeztetési Osztály is múködött, mely egyszervi (izolált légzési) elégtelen betegek kezelését igen hatékonyan végezte (körülbelül 100 beteg/év) [15], így a nem invazív lélegeztetési céllal intenzív osztályra kerülő betegek száma eleve kevesebb volt.

Az SE AITK LIO által felvett betegek jelentős része $(36,5 \%)$ iniciálisan nem invazív lélegeztetésben részesült, ami hasonló a nem invazív lélegeztetés terén tapasztalt nyugat-európai országokban jellemző arányhoz (34\%) [11]. Az általunk észlelt konverziós arány (az invazív lélegeztetésre való áttérés szükségességének aránya) 24,5\% volt, ami az irodalmi adatok alapján (30-60\%) igen hatékony gyakorlatot jelez $[1,8,11,17]$.

Az APACHE II- és SAPS II-pontszámok a betegeink körében magasak voltak, ami mutatja a felvett kritikus állapotú betegek állapotának súlyosságát.

Az intenzív osztályon klasszikusan használt mortalitásbecslő pontrendszerek a tényleges mortalitásnál magasabb értékeket jeleztek elő $(37,5 \%$, illetve $38,5 \%$ vs. $16,9 \% ; \mathrm{p}<0,001)$, amiben szerepet játszhat az a tény, hogy az osztályon igen nagy arányban használtunk a mortalitást ismerten csökkentő gyakorlatokat (nem invazív lélegeztetés, nem invazív lélegeztetés használata invazív lélegeztetésről való leszoktatáshoz, szedáció minimális alkalmazása invazívan lélegeztetett betegeknél, korai mobilizáció alkalmazása invazívan lélegeztetett betegeknél).

Az APACHE II- és SAPS II-pontszámok szignifikáns különbséget mutattak iniciálisan invazívan és nem invazívan lélegeztetett betegeknél $(21$ [17; 29] vs. 19 [16; $23\rfloor ; p=0,002$, illetve $43\lfloor 34 ; 56\rfloor$ vs. $33\lfloor 27 ; 41\rfloor$; $\mathrm{p}<0,001)$; az APACHE II esetén a nem túl nagy statisztikai különbséget néhány magas pontszámmal rendelkező beteg okozta. Mindkét pontrendszer esetén jelentős átfedés észlelhető a két betegcsoport között, így következtetéseink szerint az iniciális lélegeztetési módot nem elsősorban a beteg állapotának súlyossága határozza meg, tehát a nem invazív technika indikációját vagy kontraindikációját nem a kritikus állapotú beteg állapotának súlyossága határozza meg.

A pontszámokban nem volt különbség a nem konvertált és a konvertált betegcsoport között, így következtetésünk szerint az APACHE II.- és SAPS II.-pontszám sem az invazív és a nem invazív lélegeztetési mód közötti döntésben, sem a nem invazív lélegeztetés sikertelenségének előrejelzésében nem segít.

Jelen betegcsoportunkban a nem invazív lélegeztetés sikertelenségének előfordulását nem a betegek kiindulási állapota, hanem inkább az indikációs kórképek befolyásolták. Az immundeficientiához kapcsolt tüdőgyulladás igen magas arányban igényelt konverziót $(71,4 \%)$, azonban a cardialis dekompenzáció és a COPD akut exacerbatiójának kezelésekor a nem invazív lélegeztetés igen sikeresnek bizonyult ( $0 \%$-os, illetve 16,7\%-os konverziós arány). Ezen adatok a kis elemszám miatt nem voltak statisztikailag értékelhetők. Következtetésünk és tapasztalatunk alapján a cardialis dekompenzáció és a COPD akut exacerbatiója kapcsán a nem invazív lélegeztetés igen nagy biztonsággal alkalmazható, míg az immundeficientiához kapcsolt tüdőgyulladás esetén a nem invazív lélegeztetés igen gondos mérlegelést igényel (a pneumonia jellege, a beteg kooperációja, izomereje).

A sikertelen nem invazív lélegeztetés analízisünk során minden betegcsoportban fokozott mortalitással járt a sikeres nem invazív lélegeztetéshez képest, azonban az ini- 
ciálisan invazívan lélegeztetett betegekhez képest nem jelentett fokozott mortalitást. Ezek az adatok nem tükrözik az irodalomban több betegcsoportban leírt sikertelen nem invazív lélegeztetés mortalitásemelő hatását. Ennek hátterében véleményünk szerint az osztályos gyakorlatunk során alkalmazott rendszeres terápiás újraértékelés és szükség esetén proaktív konverziós politika állhat, melynek célja kifejezetten az elkésett konverzióból származó mortalitásemelkedés megelőzése.

\section{Következtetés}

Adataink rámutatnak arra, hogy a nem invazív lélegeztetés magyar viszonylatban is széles körü indikációval, sikeresen alkalmazható kezelési mód. Adataink a továbbiakban megerősítik azt, hogy a nem invazív lélegeztetés meghatározott indikációs körrel rendelkező terápiás lehetőség, mely bizonyos betegcsoportokban, így a COPD akut exacerbatiójában (hypercapniás légzési elégtelenekben) és cardialis eredetú tüdőödémában az elsőként választandó lélegeztetési forma. Adataink ugyanakkor felhívják a figyelmet arra, hogy a nem megfelelő indikációval végzett nem invazív lélegeztetés sikertelensége és várható mortalitása fokozott lehet.

Anyagi támogatás: A közlemény megírása és a kutatási munka anyagi támogatásban nem részesült.

Szerzôi munkamegosztás: V. L., L. A.: A kézirat megírása. V. L., B. Sz., T. E.: Adatgyújtés. V. L., L. A.: Statisztikai elemzés. L. A., G. J.: A kutatási munka felügyelete. A kézirat végleges változatát valamennyi szerző elolvasta és jóváhagyta.

Érdekeltségek: A szerzóknek nincsenek érdekeltségeik.

\section{Irodalom}

[1] Demoule A, Chevret S, Carlucci A, et al. Changing use of noninvasive ventilation in critically ill patients: trends over 15 years in francophone countries. Intensive Care Med. 2016; 42: 82-92.

[2] Rochwerg B, Brochard L, Elliott MW, et al. Official ERS/ATS clinical practice guidelines: noninvasive ventilation for acute respiratory failure. Eur Respir J. 2017; 50: 1602426.
[3] Pisani L, Corcione N, Nava S. Management of acute hypercapnic respiratory failure. Curr Opin Crit Care 2016; 22: 45-52.

[4] Navalesi P, Gregoretti C, Antonelli M. Noninvasive ventilation and outcomes among immunocompromised patients. JAMA 2016; 315: 1902.

[5] Jaber S, Lescot T, Futier E, et al. Effect of noninvasive ventilation on tracheal reintubation among patients with hypoxemic respiratory failure following abdominal surgery: a randomized clinical trial. JAMA 2016; 315: 1345-1353.

[6] Hernández G, Vaquero C, Colinas L, et al. Effect of postextubation high-flow nasal cannula vs noninvasive ventilation on reintubation and postextubation respiratory failure in high-risk patients: a randomized clinical trial. JAMA 2016; 316: 1565-1574.

[7] Carteaux G, Millán-Guilarte T, De Prost N, et al. Failure of noninvasive ventilation for de novo acute hypoxemic respiratory failure: role of tidal volume. Crit Care Med. 2016; 44: 282-290.

[8] Ozyilmaz E, Ugurlu AO, Nava S. Timing of noninvasive ventilation failure: causes, risk factors, and potential remedies. BMC Pulm Med. 2014; 14: 19.

[9] Maheshwari V, Paioli D, Rothaar R, et al. Utilization of noninvasive ventilation in acute care hospitals: a regional survey. Chest 2006; 129: 1226-1233.

[10] Carlucci A, Delmastro M, Rubini F, et al. Changes in the practice of non-invasive ventilation in treating COPD patients over 8 years. Intensive Care Med. 2003; 29: 419-425.

[11] Crimi C, Noto A, Princi P, et al. A European survey of noninvasive ventilation practices. Eur Respir J. 2010; 36: 362-369.

[12] Nasiłowski J, Leszczyk M, Bura M, et al. Survey of non-invasive ventilation use for acute respiratory failure in respiratory wards in Poland. Eur Respir J. 2011; 38: 3798.

[13] Nasiłowski J, Zieliński J, Chazan R. Uneven use of noninvasive ventilation in acute respiratory failure in Europe. Eur Respir J. 2011; 37: 1536.

[14] Lorx A, Pénzes I. Forms, modes and equipment of noninvasive ventilation. [A nem invazív lélegeztetés formái, módjai, eszközei.] Med Thorac. 2003; 56: 101-109. [Hungarian]

[15] Lorx A, Bartusek D, Losonczy G, et al. Non-invasive respiratory unit in the Hungarian health care system. [Nem invazív légzési osztály a hazai ellátórendszerben.] Orv Hetil. 2012; 153: 918921. [Hungarian]

[16] Gresz M. Some more parameters of utilization of intensive care units in Hungary. [Az intenzív osztályok kihasználtságának néhány újabb paramétere.] Orv Hetil. 2011; 152: 1813-1817. [Hungarian]

[17] Corrêa TD, Sanches PR, de Morais LC, et al. Performance of noninvasive ventilation in acute respiratory failure in critically ill patients: a prospective, observational, cohort study. BMC Pulm Med. 2015; 15: 144-151.

(Valkó Luca dr., Budapest, Üllói út 78., 1085 e-mail: valko.luca@med.semmelweis-univ.hu) 